\title{
ALBI SCORE AS A PREDICTOR OF SURVIVAL IN PATIENTS WITH COMPENSATED CIRRHOSIS RESECTED FOR HEPATOCELLULAR CARCINOMA: EXPLORATORY EVALUATION IN RELATIONSHIP TO PALBI AND MELD LIVER FUNCTION SCORES
}

\author{
Tonći Božin ${ }^{1}$, Sanda Mustapić ${ }^{1}$, Tomislav Bokun ${ }^{1}$, Leonardo Patrlj ${ }^{2,3}$, Mislav Rakić \\ Gorana Aralica ${ }^{3,4}$, Milan Kujundžić1, ${ }^{1,3}$, Vladimir Trkulja ${ }^{5}$ and Ivica Grgurević ${ }^{1,3}$ \\ ${ }^{1}$ Department of Gastroenterology, Hepatology and Clinical Nutrition, Dubrava University Hospital, \\ Zagreb, Croatia; ${ }^{2}$ Department of Abdominal Surgery, Dubrava University Hospital, Zagreb, Croatia; \\ ${ }^{3}$ University of Zagreb, School of Medicine, Zagreb, Croatia; ${ }^{4}$ Department of Pathology, \\ Dubrava University Hospital, Zagreb, Croatia; ${ }^{5}$ Department of Pharmacology, University of Zagreb, \\ School of Medicine, Zagreb, Croatia
}

\begin{abstract}
SUMMARY - The aim of the study was to explore predictive value of the ALBI, PALBI and MELD scores on survival in patients resected for hepatocellular carcinoma with compensated liver cirrhosis and no macrovascular infiltration. In this retrospective study, longitudinal survival analysis was performed. We analyzed patient/tumor characteristics and MELD, ALBI and PALBI scores as liver function tests for predicting survival outcome. Survival was analyzed from the date of liver resection until death, liver transplantation, or end of follow-up. Patients were stratified for age, cirrhosis etiology, presence of esophageal varices, hepatocellular carcinoma stage, microvascular invasion, histologic differentiation, and resection margins. We identified 38 patients (alcoholic cirrhosis in $84.2 \%$ of patients) resected over an 8-year period. Median preoperative MELD score was 8, ALBI score -2.63, and PALBI score -2.38. During the follow-up period, 24 patients died. Estimated median survival time was 36 months. Microvascular invasion was observed in 33 patients. Higher ALBI score was associated with $23.1 \%$ higher relative risk of death. PALBI score was associated with $12.1 \%$ higher relative risk of death, whereas MELD score was not associated with the risk of death. In conclusion, ALBI score demonstrated significant predictive capabilities for survival in patients with compensated cirrhosis resected for hepatocellular carcinoma.
\end{abstract}

Key words: Carcinoma, Hepatocellular; Liver Cirrhosis; Liver Function Tests; Hepatectomy; Liver Transplantation; Esophageal and Gastric Varices; Liver Cirrhosis, Alcoholic; Follow-Up Studies; Survival

\section{Introduction}

Hepatocellular carcinoma (HCC) is a complex disease with many contributing factors and poor overall prognosis ${ }^{1}$. Currently, data report a 5 -year overall sur-

Correspondence to: Assist. Prof. Ivica Grgurević, $M D, P h D$, Department of Gastroenterology, Hepatology and Clinical Nutrition, University of Zagreb, School of Medicine, Dubrava University Hospital, Av. Gojka Šuška 6, HR-10000 Zagreb, Croatia

E-mail: ivica.grgurevic@zg.htnet.hr

Received September 19, 2017, accepted April 12, 2018 vival of $50 \%$ for curative treatment of $\mathrm{HCC}^{2}$. Patient age, size and number of tumors, vascular invasion, histologic grading, and portal vein invasion have all been demonstrated to influence recurrence after surgery ${ }^{3-5}$. Prognostic modeling in HCC is complex because underlying diseases and residual liver function should be taken into account. The Barcelona Clinic Liver Cancer (BCLC) classification is most commonly used in clinical practice ${ }^{6-8}$. According to BCLC, hepatic curative resection might be achieved in patients with early 
stage $\mathrm{HCC}$, provided normal clinical performance status and preserved liver function [bilirubin levels $<1$ $\mathrm{mg} / \mathrm{dL}$, absence of portal hypertension, and ChildPugh (C-P) class - A status] 2,9. C-P classification was developed to stratify perioperative risk for patients with cirrhosis undergoing various types of surgeries $^{10,11}$. Due to its subjective variables, it has proved to be of variable reliability ${ }^{12,13}$. The Model for End-Stage Liver Disease (MELD) score is a more sophisticated tool developed initially to assess the perioperative risk in cirrhotic candidates for transjugular intrahepatic portosystemic shunt (TIPS), and is based on objective measurements (serum creatinine, total bilirubin, international normalized ratio and serum sodium $)^{14,15}$. Later on, it proved valuable in predicting outcome for other surgical procedures in these patients ${ }^{13}$. In this setting, its prognostic value is superior to that of the $\mathrm{C}-\mathrm{P}$ classification and has also been suggested for risk stratification in HCC patients ${ }^{16,17}$. Over the past several years, however, a new scoring system has been developed specifically in patients with HCC. Based on observational and clinical trial data in $\mathrm{HCC}$ patients from Europe, Japan and China, a score based on serum albumin and bilirubin (ALBI) was developed and shown to be able to identify different risk patient subsets within the $\mathrm{C}-\mathrm{P}$ grade $\mathrm{A}^{18}$. Based on this score, $\mathrm{pa}-$ tients are graded as grade 1 (lowest mortality risk) (ALBI score $\leq 2.60$ ), ALBI grade 2 (score $-2.60<$ and $\leq 1.39$ ) (intermediate mortality risk) and grade 3 (score $>-1.39$ ) (highest mortality risk) ${ }^{18}$. The score was shown to perform well at different C-P grades, different tumor sizes or tumor stages, and across different treatment modalities ${ }^{18,19}$. An extension of ALBI is PALBI score $^{20}$ that additionally includes platelet count as an indicator of portal hypertension. Based on PALBI, patients are classified as grade 1 (score $\leq 2.53$ ), grade 2 (score $-2.53<$ and $\leq 2.09$ ) and grade 3 (score >-2.09). In one study, PALBI was suggested to better predict mortality in HCC patients across different stages and treatment modalities than ALBI, and both scores were superior to $\mathrm{MELD}^{19}$. So far, ALBI was extensively evaluated in respect to predicting mortality and/or posthepatectomy liver failure after HCC treatment (resection, ablation, transarterial chemoembolization, systemic therapy) in mixed European-Japanese-Chinese cohorts ${ }^{18}$ or Japanese or Chinese cohorts ${ }^{21,22}$. In one study, ALBI was found to be an independent predictor of progression-free survival, but not overall sur- vival $^{22}$, whereas in another one it better predicted posthepatectomy liver failure than C-P classification ${ }^{21}$. Specifics of these major studies were that they included patients both with and without macrovascular involvement (reported prevalence 7.8\%-39\%) ${ }^{18,19}$, some with different $\mathrm{C}-\mathrm{P}$ grades, or with $\mathrm{HCC}$ but not cirrhotic, and with prevailing hepatitis $\mathrm{B}$ or hepatitis $\mathrm{C}$ etiologies of cirrhosis ${ }^{18,19,23}$. Obviously, ALBI and its extension PALBI have a potential of risk stratification in HCC patients, but it is also clear that further validation is needed since their performance might differ depending on the underlying disease and/or other regional specifics. In Croatia, being a southern-middle European country, alcohol abuse is the most prevalent cause of cirrhosis/ $\mathrm{HCC}^{24,25}$. With this in mind, and considering that the best candidates for curative resection are $\mathrm{C}-\mathrm{P}$ grade $\mathrm{A}$ patients, without macrovascular tumor infiltration ${ }^{3}$, we undertook an exploratory evaluation of ALBI in relation to PALBI and MELD as predictors of overall survival in a cohort of Croatian HCC patients with $\mathrm{C}-\mathrm{P}$ grade $\mathrm{A}$ cirrhosis without macrovascular involvement.

\section{Patients and Methods}

\section{Ethics and general design}

This single-center, retrospective analysis was based on a prospectively assembled institutional database on HCC patients and was approved by the institutional Ethics Committee.

\section{Patients}

Candidates for inclusion were patients with $\mathrm{HCC}$ and compensated ( $\mathrm{C}-\mathrm{P}$ grade $\mathrm{A}$ ) liver cirrhosis that underwent curative tumor resection (with the indication based on the BCLC system) between January 1, 2006 and July 31, 2014, in whom macrovascular infiltration was positively excluded.

\section{Patient evaluations and follow-up}

Preoperatively, patients were assessed for etiology of liver disease; presence of ascites was assessed using ultrasound and imaging modalities (computed tomography $(\mathrm{CT})$ or magnetic resonance (MRI)); presence of esophageal varices was assessed on endoscopy; a C-P grade was assigned ${ }^{10}$; and MELD score was determined ${ }^{16}$. Total tumor mass was defined as the sum of all tumor diameters; vascular infiltration was de- 
fined as the presence of tumor thrombus in any hepatic or portal vein based on CT or MRI. Presence of extrahepatic metastases was also analyzed based on CT or MRI. After the surgery, patients were followedup according to the standards of good practice in line with the professional guidelines ${ }^{7}$. For the purpose of the present analysis, patients were followed-up until death or liver transplantation (censored) as assessed from the database, and all others were contacted during the second half of December 2015 and were treated as censored if alive, or death dates were obtained from the next of kin. ALBI and PALBI scores were calculated from the archived laboratory work-up. ALBI score $=(\log 10$ bilirubin $\times 0.66)+($ albumin $x$ $-0.085)^{18}$. PALBI score $=(2.02 \times \log 10$ bilirubin $)-$ $\left[0.37 \mathrm{x}(\log 10 \text { bilirubin })^{2}\right]-(0.04 \mathrm{x}$ albumin $)-(3.48 \mathrm{x}$ $\log 10$ platelets $)+\left[1.01 \times(\log 10 \text { platelets })^{2,20}\right.$.

\section{Surgical procedure}

The approach to the liver was through right subcostal 'J' laparotomy, followed by liver mobilization. Intraoperative ultrasonography (US) was used to identify the exact localization of the tumor and its relationship to blood vessels. These data were important to determine the type of liver resection. Liver resection was performed by blunt-clamp dissection technique, which allows visualization of intrahepatic vessels and individual ligation of major blood vessels or bile ducts. It was performed with the use of the LigaSure device (Medtronic, Covidien, USA) ${ }^{26,27}$. In all patients, intermittent Pringle maneuver was used to avoid blood loss during liver transection.

\section{Pathological analysis}

Resected specimens were routinely formalin fixed, paraffin embedded and stained by hemalaun-eosin (HE). HE slides were analyzed for histologic grade, presence of tumor-free margins and microvascular invasion. Histologic grade was determined using the 2010 WHO classification ${ }^{28}$. Tumor free margins were measured on routine $\mathrm{HE}$ slides as the shortest distance from tumor border to the liver parenchyma resection margin inked by tissue dye. Microscopic vascular invasion $(\mathrm{mVI})$ was defined as tumor within a vascular space lined by the endothelium that was visible only by microscopy. A minimum of $5 \mathrm{HE}$ slides from the transition zone between tumor and peritumoral liver parenchyma were examined by two expert pathologists to determine mVI. Furthermore, one section of nontumoral liver tissue, which was most distant from tumor tissue, was also examined for $\mathrm{mVI}^{29}$.

\section{Data analysis}

Data analysis was guided by the need to achieve a reasonably meaningful evaluation of predictivity of liver function scores within a limited sample size. Therefore, the Cox proportional hazard models had to be carefully built. In this respect, and in order to avoid aliasing between potential baseline predictors, the first step was to evaluate univariate associations between subject/tumor characteristics, apart from tumor size and liver function scores (or their elements), and survival. The second step was to investigate the relationship between tumor size and liver function tests, and between tumor size, liver function tests and potentially identified univariate survival predictors. In the first step, only the Eastern Cooperation Oncology Group (ECOG) performance status was found to be associated with survival. In the second step, higher tumor size was found to be associated with worse ALBI and PALBI scores, and worse ECOG status was found to be associated with a larger tumor size, worse ALBI and worse PALBI scores. Therefore, final analysis was performed as follows: (a) the impact of tumor size on survival was assessed in a Cox model with adjustment for age and $\mathrm{mVI}$ (Model 1). No adjustment was done for ECOG status since worse ECOG was associated with larger tumor size; (b) the impact of ALBI score on survival was assessed in a Cox model with the same adjustments (Model 2); ECOG was skipped for the same reason as in Model 1. The model did not adjust for tumor size because (i) the main evaluation of $\mathrm{ALBI}^{18}$ was done without adjustment for tumor size, and (ii) larger tumor size was associated with worse ALBI; (c) the impact of PALBI was assessed in a Cox model (Model 3) with the same adjustments as in Model 2 (and for the same reasons); and (d) the impact of MELD (Model 4) was assessed under the same conditions as the impact of ALBI and PALBI.

\section{Results}

\section{Patient characteristics}

Of the 42 patients that underwent liver resection for HCC during the index period, four patients were classified as $\mathrm{C}-\mathrm{P}$ stage $\mathrm{B}$ (one also having macroscopic 
Table 1. Characteristics of study patients $(N=38)$

\begin{tabular}{|c|c|c|c|}
\hline Demographics & & Laboratory tests & \\
\hline Age (yrs) & $66(39-82)$ & Total bilirubin $(\mathrm{mmol} / \mathrm{L})$ & $13(7.1-36.3)$ \\
\hline Men, n (\%) & $29(76 \%)$ & Albumin $(\mathrm{g} / \mathrm{L})$ & $40(25.0-54.3)$ \\
\hline Clinical presentation & \multirow{7}{*}{$\begin{array}{l}32(84.2 \%) \\
2(5.2 \%) \\
3(7.8 \%) \\
1(2.6 \%)\end{array}$} & International norm. ratio & $1.1(0.9-2.1)$ \\
\hline Etiology of cirrhosis, $\mathrm{n}(\%)$ & & Aspartate aminotransferase (U/L) & $47(14-281)$ \\
\hline Ethanol abuse & & Alanine aminotransferase (U/L) & $42(5-260)$ \\
\hline Hepatitis B virus & & Platelets $\left(\mathrm{x} 10^{9} / \mathrm{L}\right)$ & $194(90-495)$ \\
\hline Hepatitis $\mathrm{C}$ virus & & Liver function scores & \\
\hline Fatty liver & & ALBI & $-2.63(-4.03--1.16)$ \\
\hline ECOG performance status, $\mathrm{n}(\%)$ & & PALBI & $-2.38(-3.41--1.23)$ \\
\hline 0 & \multirow{6}{*}{$\begin{array}{l}7(18.4 \%) \\
24(63.2 \%) \\
5(13.2 \%) \\
2(5.2 \%) \\
4(10.5 \%) \\
5(13.1 \%)\end{array}$} & MELD & $8(6-14)$ \\
\hline 1 & & Follow-up and survival & \\
\hline 2 & & Cumulative deaths & $24(63.2 \%)$ \\
\hline 3 & & Time to $1^{\text {st }}$ death (months) & 0.5 \\
\hline Ascites, $\mathrm{n}$ & & Time to last death (months) & 62 \\
\hline Esophageal varices, n (\%) & & Time to $1^{\text {st }}$ censoring (months) & 6 \\
\hline Tumor characteristics & \multirow{4}{*}{$\begin{array}{l}85(30-240) \\
8(21.1 \%)\end{array}$} & Time to last censoring (months) & 57 \\
\hline Total tumor mass (mm); median(range) & & & \\
\hline Extrahepatic involvement, n (\%) & & & \\
\hline HCC stage, n (\%) & & & \\
\hline 1 & $6(15.7 \%)$ & & \\
\hline 2 & $23(60.5 \%)$ & & \\
\hline 3 & $3(7.8 \%)$ & & \\
\hline HCC histologic grade, $\mathrm{n}(\%)$ & & & \\
\hline Poorly differentiated & $3(7.8 \%)$ & & \\
\hline Moderately differentiated & $25(65.7 \%)$ & & \\
\hline Well differentiated & $10(26.3 \%)$ & & \\
\hline Microvascular invasion, $\mathrm{n}(\%)$ & $33(86.8 \%)$ & & \\
\hline Free resection margins, $\mathrm{n}(\%)$ & $26(68.4 \%)$ & & \\
\hline
\end{tabular}

Data are expressed as medians (range from minimum to maximum) or number (n) and percentage (\%) of participants per group; ECOG = Eastern Cooperation Oncology Group; ALBI = albumin-bilirubin; PALBI = platelet-albumin-bilirubin; MELD = model for end-stage liver diseases; HCC = hepatocellular carcinoma; HCC stage (1 - within Milan; 2 - outside Milan but no vascular infiltration or extrahepatic metastasis; 3 - presence of vascular infiltration or extrahepatic metastasis intraoperatively)

vascular invasion), hence 38 patients were included in the analysis. Table 1 summarizes their characteristics. Men prevailed, in line with the fact that virtually the only cause of cirrhosis was ethanol abuse $(n=32)$. Their physical status was overall satisfactory, since $31 \mathrm{had}$ ECOG performance status 0 or 1 , while ascites and esophageal varices were sporadic. Total tumor mass varied between 30 and $240 \mathrm{~mm}$ and eight patients had extrahepatic involvement. Stage 1 and $2(n=29)$ and poorly or moderately differentiated tumors $(n=28)$ prevailed. In most patients $(\mathrm{n}=33), \mathrm{mVI}$ was observed.
ALBI score values ranged between -4.03 and -1.16 . Considering the small sample, subjects were not categorized by ALBI grade, but 20 patients had values corresponding to ALBI grade $1(\leq 2.60), 17$ had values fitting ALBI grade $2(-2.60<$ and $\leq 1.39)$ and one patient had a score to fit ALBI grade 3. Similarly, PALBI score ranged between -3.41 and -1.23 , where 13 patients had values fitting grade $1(\leq 2.53), 18$ fell within grade $2(-2.53<$ and $\leq 2.09)$ and seven fitted grade 3. MELD score range was 6-14, with seven patients with values $>10$. 
Survival not accounting for tumor size and liver function scores

Overall, 24 (63.2\%) patients died during the observed period and estimated median survival was 36 months (Fig. 1). First death occurred 0.5 months after the surgery and time of the last observed death was 62 months (Table 1). Two patients were censored at the

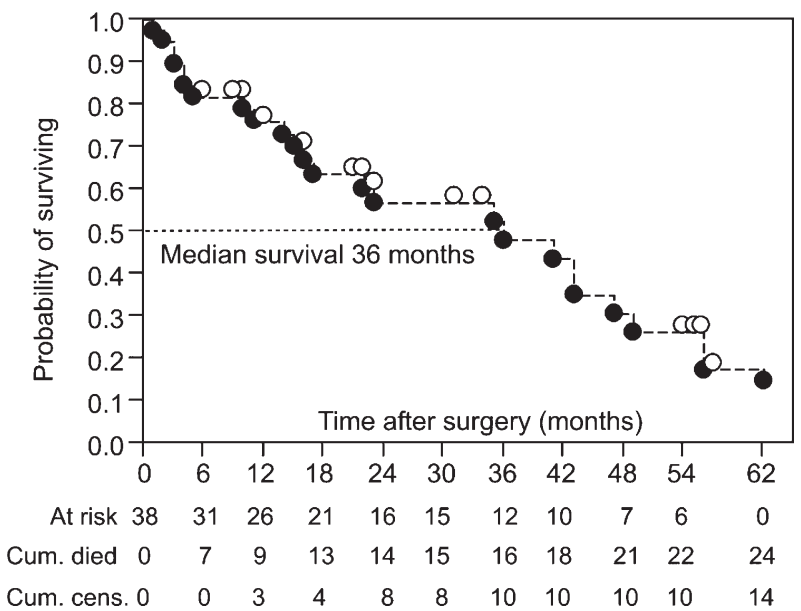

Fig. 1. Kaplan-Meier product-limit survival curve summarizing survival in the observed cohort.

Open circles above the line indicate censored observations; full circles in-between the curve indicate deaths time of liver transplantation - one 6 months after resection (shortest censored time) and another one after 16 months. Both were alive at the end-of-follow up date (December 31, 2015). Not counting tumor size and liver function scores (or elements used for their calculation), in this limited sample only ECOG performance status was univariately associated with survival: all seven patients with ECOG 2 or 3 died during the observed period (estimated median survival 11 months), while $17 / 31$ with ECOG 0 or 1 died (estimated median survival 41 months) - age-adjusted $\mathrm{HR}=2.86$ (95\% CI 1.06-6.98; $\mathrm{p}=0.039$ ).

\section{Relationship between different liver function tests, tumor size and ECOG status}

With adjustment for age, higher tumor size was associated with higher (worse) ALBI and PALBI scores, and no association was observed with MELD score (Table 2). Also, higher (worse) ECOG status (2 or 3 vs. 1 or 0 ) was univariately associated with larger tumor size and higher (worse) ALBI and PALBI scores (Table 3). No association was found with MELD score.

\section{Exploration of the ALBI, PALBI and MELD predictive value}

Considering the interrelationships observed between tumor size, liver function scores and ECOG

Table 2. Partial bivariate correlations (age-adjusted) between tumor size and liver function scores (Pearson correlation coefficients and $p$-values)

\begin{tabular}{|l|l|l|l|l|}
\hline & Tumor size & ALBI & PALBI & MELD \\
\hline Tumor size $(\mathrm{mm})$ & 1.000 & $0.356 ; 0.031$ & $0.408 ; 0.012$ & $0.065 ; 0.701$ \\
ALBI score & --- & 1.000 & $0.855 ;<0.001$ & $0.367 ; 0.025$ \\
PALBI score & --- & --- & 1.000 & $0.412 ; 0.011$ \\
\hline
\end{tabular}

ALBI = albumin-bilirubin; PALBI = platelet-albumin-bilirubin; $\mathrm{MELD}=$ model for end-stage liver diseases

Table 3. Tumor size, albumin-bilirubin (ALBI), platelet-albumin-bilirubin (PALBI) and model for end-stage liver disease (MELD) score values by patient subset based on Eastern Cooperation Oncology Group (ECOG) performance status

\begin{tabular}{|l|l|l|l|}
\hline & ECOG 2-3 $(\mathrm{n}=7)$ & ECOG 0-1 $(\mathrm{n}=31)$ & Difference $(95 \% \mathrm{CI}) ; \mathrm{p}$-value* \\
\hline Tumor size $(\mathrm{mm})$ & $120 ;(52-200)$ & $75(30-240)$ & $40(0$ to 79$) ; 0.057$ \\
ALBI score & $-2.13 \pm 0.63$ & $-2.68 \pm 0.58$ & $0.55(0.05$ to 1.05$) ; 0.031$ \\
PALBI score & $-2.04 \pm 0.51$ & $-2.47 \pm 0.39$ & $0.43(0.08$ to 0.78$) ; 0.017$ \\
MELD score & $8(6-13)$ & $7(6-14)$ & $1(-1$ to 2$) ; 0.411$ \\
\hline
\end{tabular}

Data are medians (range from minimum to maximum) or mean \pm SD. Depicted are unadjusted differences between the two subsets with $95 \%$ confidence intervals (CI); ${ }^{*}$ Median difference (approximately $95.1 \% \mathrm{CI}$ ) by Mann-Whitney test for tumor size and MELD score, mean difference by t-test for ALBI and PALBI scores 
Table 4. Association between tumor size, ALBI score, PALBI score and MELD score with the risk of all-cause death. Four separate Cox proportional hazard models were fitted to time-to event data in the observed cohort successively testing the risk associated with increasing tumor size, ALBI score, PALBI score and MELD score, with adjustment for age and microvascular invasion (see Patients and Methods - Data analysis for details on model building)

\begin{tabular}{|l|l|l|}
\hline & HR (95\% CI) & $\mathrm{p}$-value \\
\hline Model 1 & & \\
\hline Tumor size (by 10 mm) & $1.247(1.116-1.407)$ & $<0.001$ \\
\hline Age (by 5 years) & $0.956(0.811-1.147)$ & 0.611 \\
\hline Microvascular invasion & $1.908(0.463-12.9)$ & 0.397 \\
\hline Model 2 & & \\
\hline $\begin{array}{l}\text { ALBI score } \\
\text { (by 0.2 points) }\end{array}$ & $1.231(1.024-1.496)$ & 0.026 \\
\hline Age (by 5 years) & $0.886(0.725-1.097)$ & 0.248 \\
\hline Microvascular invasion & $2.182(0.514-15.0)$ & 0.311 \\
\hline Model 3 & $1.121(0.890-1.413)$ & 0.332 \\
\hline $\begin{array}{l}\text { PALBI score } \\
\text { (by 0.2 points) }\end{array}$ & $0.936(0.778-1.147)$ & 0.462 \\
\hline Age (by 5 years) & $3.336(0.865-22.1)$ & 0.084 \\
\hline Microvascular invasion & $0.886(0.528-1.254)$ & 0.517 \\
\hline Model 4 & $0.960(0.797-1.177)$ & 0.683 \\
\hline $\begin{array}{l}\text { MELD score } \\
\text { (by 2 points) }\end{array}$ & $4.554(1.215-29.9)$ & 0.022 \\
\hline Age (by 5 years) &
\end{tabular}

ALBI = albumin-bilirubin; PALBI = platelet-albumin-bilirubin; MELD $=$ model for end-stage liver diseases

status, indicating that these variables to a great extent aliased each other, the following approach was implemented: age and $\mathrm{mVI}$ were included into each model; then a separate model was fitted to estimate the effect of tumor size, ALBI score, PALBI score and MELD score. With adjustment for age and $\mathrm{mVI}$, tumor size was a strong predictor of death (Table 4); a $10 \mathrm{~mm}$ increase in tumor size was associated with $24.7 \%$ higher relative risk of death. Increase ('worsening') in ALBI score by 0.2 units was associated with a similar effect, i.e. $23.1 \%$ higher relative risk of death (Table 4). Increase ('worsening') in PALBI score (by 0.2 units) was associated with $12.1 \%$ higher relative risk of death, but the effect did not attain statistical significance (Table 4). Increase in MELD did not appear to be associated with the risk of death (Table 4).

\section{Discussion}

Results of this study revealed tumor size and ALBI score as strong predictors of postoperative survival in a cohort of Croatian patients with compensated, mostly alcoholic liver cirrhosis resected for HCC. ALBI score appeared superior to PALBI and MELD in this setting. Our cohort was interesting because alcohol abuse was the predominant cause of cirrhosis and macrovascular invasion was excluded preoperatively. This is important due to geographical differences in $\mathrm{HCC}$ patient profiles. Since the prevailing data on this issue come from Asia where the etiologic factors for $\mathrm{HCC}$ are different (viral causes predominate), our data could be interesting for the European population since alcohol is a more prevalent cause of chronic liver disease in this area ${ }^{30}$. Factors predicting survival after liver resection for HCC include tumor stage (tumor size, histologic grade, presence of vascular invasion and metastasis), surgical technique (achievement of free resection margins), residual liver function, as well as the presence and severity of portal hypertension ${ }^{3,31}$. Not counting tumor size and liver function scores, in this limited sample only ECOG performance status was univariately associated with survival. However, higher ECOG performance status significantly correlated with the ALBI and PALBI scores, whereas no association was found with the MELD score. Also, larger tumor size was associated with higher ALBI and PALBI, but not higher MELD. The impact of other variables on survival such as the presence of $\mathrm{mVI}$, presence of esophageal varices, and extension of liver resection could not be assessed from this small sample data since the majority of patients were positive or negative for each of these categories, leaving only few patients available for comparison and making statistical evaluation unreliable. The significant prognostic value of ECOG performance status is not surprising taking into account significant aliasing with tumor size and liver function scores. Multivariate modeling identified total tumor mass as a strong predictor of death with each 10 $\mathrm{mm}$ increase in size being associated with $24.7 \%$ higher relative risk of death in our cohort (Table 4). In addition to this, $27 / 38(73.7 \%)$ tumors were moderately to poorly differentiated. According to literature data, tumor size and high histologic grade are predictors of $\mathrm{mVI}^{31}$ and presence of extrahepatic metastases $^{32}$. Indeed, $\mathrm{mVI}$ and extrahepatic metastases were 
detected in 33/38 (86.8\%) and 3/38 (7.8\%) of our patients, respectively. Such a high prevalence of $\mathrm{mVI}$ and metastases could account for the poorer overall estimated survival time of 36 months observed in our study, and could indicate poor patient stratification at enrolment. According to literature data, HCC with $\mathrm{mVI}$ is found in $35 \%$ of cases and the prevalence of lymph node metastases below the diaphragm is $2 \%$ to $3 \%{ }^{29,30}$. Free resection margins were achieved in $68.4 \%$ of patients, we speculate due to the high median tumor mass found in this cohort. At the time of diagnosis, liver function was evaluated using the $\mathrm{C}-\mathrm{P}$ score and MELD score. All of the patients resected were C-P class $\mathrm{A}$ and had median MELD score 8. The biggest drawback of the C-P score refers to patients who fall around the cutoff points, which are arbitrary, who may thus be classified as having a different risk. Johnson et al. ${ }^{17}$ found that $\log _{10}$ bilirubin and albumin were consistently statistically significant predictors of survival. When C-P grade A patients were reclassified into ALBI grade 1 or 2 , there was a 10 -month difference in survival between the two ALBI grades ${ }^{18}$. When incorporated into the BCLC system, the performance of ALBI grades was similar to the C-P system in a multicenter study with the majority of patients coming from Japan and China. Nevertheless, ALBI upstaged $4.8 \%$ of $\mathrm{HCC}$ patients and survival difference between the restaged patients was significant ${ }^{22}$. The median ALBI score in our data was -2.63 . When adjusted for age and $\mathrm{mVI}$ 'worsening' ALBI score was associated with $23.1 \%$ higher relative risk of death (Table 4). When compared with data reported by Johnson et al. ${ }^{18}$, our data show a similar effect of ALBI grade on survival in adjustment to tumor size. With liver function ranging from ALBI -4.03 to -1.16 , it is clear that our cohort of patients was indeed very heterogeneous and that $\mathrm{C}-\mathrm{P}$ is not sensitive enough to further stratify these patients. Together with the burden of tumor size, these findings could explain difference in survival observed in our cohort (shortest and longest time from surgery to death 0.5 and 62 months, respectively). Although PALBI score was associated with 12.1\% higher relative risk of death when adjusted for tumor size and $\mathrm{mVI}$, the effect did not attain statistical significance in our cohort and MELD was not associated with the risk of death at all (Table 4). This may have been expected since both PALBI and MELD contain additional components to assess the risk across the worsening liver function stages. Namely, PALBI includes platelets as the indicator of portal hypertension, and MELD score is specifically designed for patients with end-stage cirrhosis (not representative for HCC patients considering liver resection) ${ }^{33,34}$. On the other hand, ALBI was originally calculated in the cohort of only C-P A patients without clinically significant portal hypertension to subclassify them according to the odds of survival following liver resection for HCC. Our cohort encompassed only C-P A patients without signs of clinically significant portal hypertension detected during preoperative work-up, which may have been the reason for not to expect significant impact of PALBI and MELD score on survival. However, this hypothetical conclusion is not strongly funded since our results arised from a small number of patients. Therefore, it might be worthy to explore, at least for PALBI, its performance on a larger cohort of patients with compensated C-P A cirrhosis without macrovascular infiltration, since some data suggest not so decisive impact of portal hypertension on survival following liver resection for $\mathrm{HCC}^{35}$. As for MELD, previous studies revealed both lower mortality and reduced morbidity in patients undergoing liver resection for HCC when MELD score was $<9^{14}$. Besides the previously mentioned limitations, MELD score is influenced greatly by creatinine level and therefore not necessarily indicative of deterioration in liver function ${ }^{32}$. The main limitation to our work was the small number of patients analyzed. For this reason, we were unable to perform more complex and informative multivariate analysis of different prognostic factors such as esophageal varices, ascites, number of segments resected and their effect on patient survival in comparison to ALBI score. In conclusion, tumor mass and ALBI score are strong predictors of outcome in patients resected for HCC and appear superior to PALBI and MELD score in predicting postoperative survival in patients with compensated cirrhosis with no macrovascular infiltration.

\section{References}

1. Llovet JM, Burroughs A, Bruix J. Hepatocellular carcinoma. Lancet. 2003;362:1907-17, http://dx.doi.org/10.1016/S0140-6736(03)14964-1

2. Forner A, Reig ME, de Lope CR, et al., editors. Current Strategy for Staging and Treatment: the BCLC Update and Future 
Prospects. Seminars in Liver Disease; 2010: (C) Thieme Medical Publishers, http://dx.doi.org/10.1055/s-0030-1247133

3. Shah SA, Cleary SP, Wei AC, et al. Recurrence after liver resection for hepatocellular carcinoma: risk factors, treatment, and outcomes. Surgery. 2007;141:330-9, http://dx.doi.org/10.1016/j.surg.2006.06.028

4. Esnaola NF, Mirza N, Lauwers GY, et al. Comparison of clinicopathologic characteristics and outcomes after resection in patients with hepatocellular carcinoma treated in the United States, France, and Japan. Ann Surg. 2003;238:711-9, http://dx.doi.org/10.1097/01.sla.0000094436.34556.ac

5. PawlikTM, Delman KA, Vauthey JN, et al. Tumor size predicts vascular invasion and histologic grade: implications for selection of surgical treatment for hepatocellular carcinoma. Liver Transpl. 2005;11:1086-92, https://doi.org/10.1002/lt.20472

6. Marrero JA, Fontana RJ, Barrat A, et al. Prognosis of hepatocellular carcinoma: comparison of 7 staging systems in an American cohort. Hepatology. 2005;41:707-16, https://doi.org/10.1002/hep.20636

7. Liver EAFTSOT. EASL-EORTC clinical practice guidelines: management of hepatocellular carcinoma. J Hepatol. 2012; 56:908-43, https://doi.org/10.1016/j.jhep.2011.12.001

8. Tan CH, Low S-CA, Thng CH. APASL and AASLD consensus guidelines on imaging diagnosis of hepatocellular carcinoma: a review. Int J Hepatol. 2011;2011, https://doi.org/10.4061/2011/519783.

9. Mazzaferro V, Regalia E, Doci R, et al. Liver transplantation for the treatment of small hepatocellular carcinomas in patients with cirrhosis. N Engl J Med. 1996;334:693-700, https://doi.org/10.1056/NEJM199603143341104

10. Child CG, Turcotte J. Surgery and portal hypertension. Major Probl Clin Surg. 1964;1:1-85.

11. Pugh R, Murray-Lyon I, Dawson J, et al. Transection of the oesophagus for bleeding oesophageal varices. Br J Surg. 1973; 60:646-9, https://doi.org/10.1002/bjs.1800600817

12. Angermayr B, Cejna M, Karnel F, et al. Child-Pugh versus MELD score in predicting survival in patients undergoing transjugular intrahepatic portosystemic shunt. Gut. 2003;52: 879-85, https://doi.org/10.1136/gut.52.6.775-a

13. Farnsworth N, Fagan SP, Berger DH, et al. Child-TurcottePugh versus MELD score as a predictor of outcome after elective and emergent surgery in cirrhotic patients. Am J Surg. 2004;188:580-3, https://doi.org/10.1016/j.amjsurg.2004.07.034

14. Montgomery A, Ferral H, Vasan R, et al. MELD score as a predictor of early death in patients undergoing elective transjugular intrahepatic portosystemic shunt (TIPS) procedures. Cardiovasc Intervent Radiol. 2005;28:307-12, https://doi.org/10.1007/s00270-004-0145-y

15. Ruf AE, Kremers WK, Chavez LL, et al. Addition of serum sodium into the MELD score predicts waiting list mortality better than MELD alone. Liver Transpl. 2005;11:336-43, https://doi.org/10.1002/1t.20329
16. Teh SH, Christein J, Donohue J, et al. Hepatic resection of hepatocellular carcinoma in patients with cirrhosis: Model of End-Stage Liver Disease (MELD) score predicts perioperative mortality. J Gastrointest Surg. 2005;9:1207-15, https://doi.org/10.1016/j.gassur.2005.09.008

17. Cucchetti A, Ercolani G, Vivarelli M, et al. Impact of Model for End-stage Liver Disease (MELD) score on prognosis after hepatectomy for hepatocellular carcinoma on cirrhosis. Liver Transpl. 2006;12:966-71, https://doi.org/10.1002/lt.20761

18. Johnson PJ, Berhane S, Kagebayashi C, et al. Assessment of liver function in patients with hepatocellular carcinoma: a new evidence-based approach - the ALBI grade. J Clin Oncol. 2014;33:550-8, https://doi.org/10.1200/JCO.2014.57.9151

19. Liu PH, Hsu CY, Hsia CY, et al. ALBI and PALBI grade predict survival for HCC across treatment modalities and BCLC stages in the MELD era. J Gastroenterol Hepatol. 2017, 32(4):879-86, https://doi.org/10.1111/jgh.13608

20. Roayaie S, Jibara G, Berhane S, et al. PALBI - an objective score based on platelets, albumin \& bilirubin stratifies HCC patients undergoing resection $\&$ ablation better than Child's classification. Hepatology. 2015;62:631A-2A.

21. Wang YY, Zhong JH, Su ZY, et al. Albumin-bilirubin versus Child-Pugh score as a predictor of outcome after liver resection for hepatocellular carcinoma. Br J Surg. 2016;103:725-34, https://doi.org/10.1002/bjs.10095

22. Harimoto N, Yoshizumi T, Sakata K, et al. Prognostic significance of combined albumin-bilirubin and tumor-node-metastasis staging system in patients who underwent hepatic resection for hepatocellular carcinoma. Hepatol Res. 2017;47(12): 1289-98, https://doi.org/10.1111/hepr.12868

23. Sun Z, Lu P, Gail MH, et al. Increased risk of hepatocellular carcinoma in male hepatitis B surface antigen carriers with chronic hepatitis who have detectable urinary aflatoxin metabolite M1. Hepatology. 1999;30:379-83, https://doi.org/10.1002/hep.510300204

24. Bosetti C, Levi F, Boffetta $\mathrm{P}$, et al. Trends in mortality from hepatocellular carcinoma in Europe, 1980-2004. Hepatology. 2008;48:137-45, https://doi.org/10.1002/hep.22312

25. Chuang S-C, La Vecchia C, Boffetta P. Liver cancer: descriptive epidemiology and risk factors other than HBV and HCV infection. Cancer Lett. 2009;286:9-14, https://doi.org/10.1016/j.canlet.2008.10.040

26. Patrlj L, Tuorto S, Fong Y. Combined blunt-clamp dissection and LigaSure ligation for hepatic parenchyma dissection: postcoagulation technique. J Am Coll Surg. 2010;210:39-44, https://doi.org/10.1016/j.jamcollsurg.2009.09.035

27. Rakic M, Patrlj L, Kopljar M, et al. Gallbladder cancer. Hepatobiliary Surg Nutr. 2014;3:221-6, https://doi.org/10.3978/j.issn.2304-3881.2014.09.03

28. Bosman FT, Carneiro F, Hruban RH, et al. WHO classification of tumours of the digestive system. Vol. 4. Geneva: World Health Organization; 2010.

29. Roayaie S, Blume IN, Thung SN, et al. A system of classifying microvascular invasion to predict outcome after resection in 
patients with hepatocellular carcinoma. Gastroenterology. 2009;137:850-5, https://doi.org/10.1053/j.gastro.2009.06.003

30. Fares N, Peron J. Epidemiology, natural history, and risk factors of hepatocellular carcinoma. Rev Prat. 2013;63:216-7, 20-2.

31. Imamura H, Matsuyama Y, Tanaka E, et al. Risk factors contributing to early and late phase intrahepatic recurrence of hepatocellular carcinoma after hepatectomy. J Hepatol. 2003; 38:200-7, https://doi.org/10.1016/S0168-8278(02)00360-4

32. Kanda M, Tateishi R, Yoshida H, et al. Extrahepatic metastasis of hepatocellular carcinoma: incidence and risk factors. Liver Int. 2008;28:1256-63, https://doi.org/10.1111/j.1478-3231.2008.01864.x
33. Durand F, Valla D. Assessment of the prognosis of cirrhosis: Child-Pugh versus MELD. J Hepatol. 2005;42:S100-S7, https://doi.org/10.1016/j.jhep.2004.11.015

34. Marić D, Klasnja B, Filipović D, Brkić S, Ruzić M, Bugarski V. Minimal hepatic encephalopathy in patients with decompensated liver cirrhosis. Acta Clin Croat. 2011 Sep;50(3):375-80. PMID: 22384773

35. Cucchetti A, Cescon M, Golfieri R, et al. Hepatic venous pressure gradient in the preoperative assessment of patients with resectable hepatocellular carcinoma. J Hepatol. 2016;64:79-86, https://doi.org/10.1016/j.jhep.2015.08.025

Sažetak

\section{INDEKS ALBI KAO PREDIKTOR PREŽIVLJENJA NAKON RESEKCIJE HEPATOCELULARNOG KARCINOMA U BOLESNIKA S KOMPENZIRANOM CIROZOM JETRE: USPOREDBA S INDEKSIMA PALBI I MELD}

\section{T. Božin, S. Mustapić, T. Bokun, L. Patrlj, M. Rakić, G. Aralica, M. Kujundžić, V. Trkulja i I. Grgurević}

Cilj je bio istražiti prediktivnu vrijednost zbira ALBI, PALBI i MELD za preživljenje bolesnika s kompenziranom cirozom reseciranih zbog hepatocelularnog karcinoma bez makrovaskularne invazije. Provedena je retrospektivna longitudinalna analiza preživljenja. Testirane su karakteristike bolesnika/tumora kao i jetreni funkcijski testovi MELD, ALBI i PALBI za predviđanje preživljenja. Bolesnici su praćeni nakon resekcije jetre do smrti, transplantacije jetre odnosno do kraja vremena praćenja. Bolesnici su kategorizirani po dobi, etiologiji ciroze, prisutnosti varikoziteta jednjaka, stadiju karcinoma, mikrovaskularnoj invaziji, histološkom stadiju i resekcijskim rubovima. Identificirali smo 38 bolesnika (alkoholna ciroza kod 84,2\% bolenika) reseciranih kroz razdoblje od 8 godina. Medijan prijeoperacijskog zbira MELD bio je 8, zbira ALBI -2,63 i zbira PALBI -2,38. Tijekom praćenja 24 bolesnika su umrla. Očekivani medijan preživljenja iznosio je 36 mjeseci. Mikrovaskularna invazija pronađena je u 33 bolesnika. Veći ALBI je bio povezan s 23,1\%, a PALBI s 12,1\% većim relativnim rizikom od smrtnog ishoda. MELD nije bio povezan sa smrtnim ishodom. Zbir ALBI je pokazao značajnu prediktivnu vrijednost preživljenja u skupini bolesnika s kompenziranom cirozom reseciranih zbog hepatocelularnog karcinoma.

Ključne riječi: karcinom, hepatocelularni; jetrena ciroza; jetra, ispitivanje funkcije; hepatektomija; jetra, transplantacija; ezofagusni i želučani varikoziteti; jetrena ciroza, alkoholna; kontrolne studije; preživljavanje 